\title{
Sexual and geographic dimorphism in northern rockhopper penguins breeding in the South Atlantic Ocean
}

\author{
Antje Steinfurth ${ }^{1,2, *, * *}$, Jenny M. Booth ${ }^{3, * *}$, Jeff White ${ }^{4}$, Alexander L. Bond ${ }^{5,6}$, \\ Christopher D. McQuaid ${ }^{3}$
}

${ }^{1}$ FitzPatrick Institute of African Ornithology, DST/NRF Centre of Excellence, University of Cape Town, Rondebosch 7700, South Africa ${ }^{2}$ RSPB Centre for Conservation Science, Royal Society for the Protection of Birds, David Attenborough Building, Cambridge, Cambridgeshire CB2 3QZ, UK

${ }^{3}$ Coastal Research Group, Department of Zoology and Entomology, Rhodes University, PO Box 94, Grahamstown 6140, South Africa ${ }^{4}$ Marshall University, Huntington, WV 25755, USA

${ }^{5}$ RSPB Centre for Conservation Science, Royal Society for the Protection of Birds, The Lodge, Sandy, Bedfordshire SG19 2DL, UK

${ }^{6}$ Bird Group, Department of Life Sciences, The Natural History Museum, Tring, Hertfordshire HP23 6AP, UK

\begin{abstract}
The Endangered northern rockhopper penguin Eudyptes moseleyi, like all penguins, is monomorphic, making sex determination of individuals in the field challenging. We examined the degree of sexual size dimorphism of adult birds across the species' breeding range in the Atlantic Ocean and developed discriminant functions (DF) to predict individuals' sex using morphometric measurements. We found significant site-specific differences in both bill length and bill depth, with males being the larger sex on each island. Across all islands, bill length contributed $78 \%$ to dissimilarity between sexes. Penguins on Gough Island had significantly longer bills, whilst those from Tristan da Cunha had the deepest. Island-specific DFs correctly classified 82-94\% of individuals, and all functions performed significantly better than chance. The model for Nightingale Island correctly classified the greatest proportion of individuals (94-95\%), while that for Tristan da Cunha performed the poorest (80-82\%). A discriminant function derived from all sites accurately sexed $86-88 \%$ of northern rockhopper penguins achieving similar accuracy to island-specific functions. While molecular techniques conclusively determine an individual's sex, morphometric measurements can provide a reliable estimate with close to $90 \%$ accuracy using a method that is less invasive and requires little technical expertise. Sexing is an important tool for meaningful interpretation of ecological data. Consideration of sex-specific differences in future studies will aid investigation of a potential sex-dependent vulnerability in this Endangered species.
\end{abstract}

KEY WORDS: Northern rockhopper penguin - Eudyptes moseleyi - Sexual dimorphism . Discriminant function analysis $\cdot$ Morphological sexing $\cdot$ Morphometrics

\section{INTRODUCTION}

Animal behaviour is often driven by sex-specific differences that affect survival, population trends and dynamics, and ecological studies of these aspects therefore require knowledge of the sex of individuals. For monomorphic species, such as many sea-

\footnotetext{
${ }^{*}$ Corresponding author: antje.steinfurth@rspb.org.uk
}

${ }^{* *}$ These authors equally contributed to this work birds, determination of individuals' sex can be challenging, and various approaches have been adopted: cloacal examination (Samour et al. 1983), vent measurements (Boersma \& Davies 1987), behavioural observations (Kerry et al. 1992, Le Bohec et al. 2008), examination by ultrasound (Hildebrandt et al. 1996), dissection (Cortés et al. 2018) and molecular analysis

() The authors 2019. Open Access under Creative Commons by Attribution Licence. Use, distribution and reproduction are unrestricted. Authors and original publication must be credited. 
(Ellegren 1996, Griffiths et al. 1998, Bertellotti et al. 2002). All of these techniques suffer important drawbacks. There is a circular argument in using behaviour to infer sex; molecular techniques or ultrasound rely on expensive equipment and cannot be applied in the field, while cloacal and vent examination require specialist skills.

While sexual dimorphism in plumage is virtually absent, monomorphic seabird species often display subtle but distinct morphological differences between the sexes (Gaston 2004). Sexual size differences are commonly used in the field to determine sex in a simple, rapid and less invasive manner compared to other methods, only requiring minimal technical expertise. In penguins, discriminant function analysis (DFA), a mathematical approach based on morphological measurements, has been applied to predict individuals' sex in several species (Table 1). However, owing to geographic variation and species-specific morphology, the discriminant functions developed are restricted to the species and often to the geographic areas in which they were obtained.

Among the 6 penguin genera, Eudyptes is the most widely distributed and sexually dimorphic genus (Croxall 1995). Poisbleau et al. (2010) derived a highly accurate discriminant function $(96.2 \%$ correct classification rate) for sexing adult southern rockhopper penguins E. chrysocome in the Falkland Islands/ Las Malvinas. The northern rockhopper penguin was formerly considered a subspecies of E. chrysocome but is now recognized as a full species (Banks et al. 2006, Jouventin et al. 2006). The 2 rockhopper penguin species are broadly similar in appearance, but northern rockhopper penguins differ from southern rockhoppers by being larger in size, having a wider supercilium and longer crest feathers (Williams 1995, Cuthbert 2013). While the southern rockhopper penguin is distributed from the southern tip of South America, the Falkland Islands/Las Malvinas and across the Southern Ocean, the northern rockhopper penguin is the most northerly breeding Eudyptes penguin, with $\sim 90 \%$ of the global population breeding on only 5 islands between $37-40^{\circ} \mathrm{S}$ in the Tristan da Cunha group in the South Atlantic Ocean (Cuthbert et al. 2009, Robson et al. 2011, BirdLife International 2018).

The present study aimed to investigate potential sexual size differences and geographic variation in northern rockhopper penguins among breeding locations across the species' relatively small distributional range in the South Atlantic Ocean. Given that previous studies predominantly found measurements of bill length (BL) and bill depth (BD) to have the great- est sexual size differences (e.g. Poisbleau et al. 2010, Campbell et al. 2016, Cappello \& Boersma 2018, Table 1), we focused on these 2 morphometrics while simultaneously using genetic analysis to confirm the sex of study individuals in order to test the reliability of the obtained discriminant functions and examine differences in measurements among islands.

\section{MATERIALS AND METHODS}

The Tristan da Cunha archipelago comprises the 3 main islands Tristan da Cunha $\left(37^{\circ} 09^{\prime} \mathrm{S}, 12^{\circ} 16^{\prime} \mathrm{W}\right)$, Inaccessible $\left(37^{\circ} 17^{\prime} \mathrm{S}, 12^{\circ} 40^{\prime} \mathrm{W}\right)$ and Nightingale $\left(37^{\circ} 25^{\prime} \mathrm{S}, 12^{\circ} 28^{\prime} \mathrm{W}\right)$, with Gough Island $\left(40^{\circ} 19^{\prime} \mathrm{S}\right.$, $9^{\circ} 56^{\prime} \mathrm{W}$ ) located approximately $380 \mathrm{~km}$ further south.

Blood samples and morphometric bill measurements from adult northern rockhopper penguins were taken during the austral summers of 2010 on Tristan da Cunha and of 2012 and 2013 on Nightingale and Gough islands. Blood was drawn from the tarsal vein of each bird using a 25-gauge needle and a $2 \mathrm{ml}$ syringe. Samples were then stored in Eppendorf tubes and frozen at -20 and $-30^{\circ} \mathrm{C}$ on Tristan da Cunha and Gough islands, respectively. On Nightingale Island, due to insufficient power supply, samples were preserved with equal volumes of $70 \%$ ethanol and kept at ambient temperature.

\subsection{Morphometrics}

For each bird, morphological measurements of BD (at a point proximal to the tip of the triangular interramal feather patch) and BL (length of exposed culmen) were taken to the nearest $0.1 \mathrm{~mm}$ using Vernier callipers as shown in Fig. 1 following Warham (1972, 1975). Repeated measures $(\geq 2)$ on both BL and BD were performed to ensure accuracy of results and hence reproducibility of measurements. Morphometric measurements were taken by J.M.B. on Tristan da Cunha, A.S. on Nightingale Island, and 3 research assistants took the morphometric measurements on Gough Island.

\subsection{Molecular-based sexing}

Sample collection was carried out on Tristan da Cunha in 2010 and on Nightingale and Gough islands in 2012/2013 as part of 2 distinct research projects. Hence, samples were analysed in 2 different 


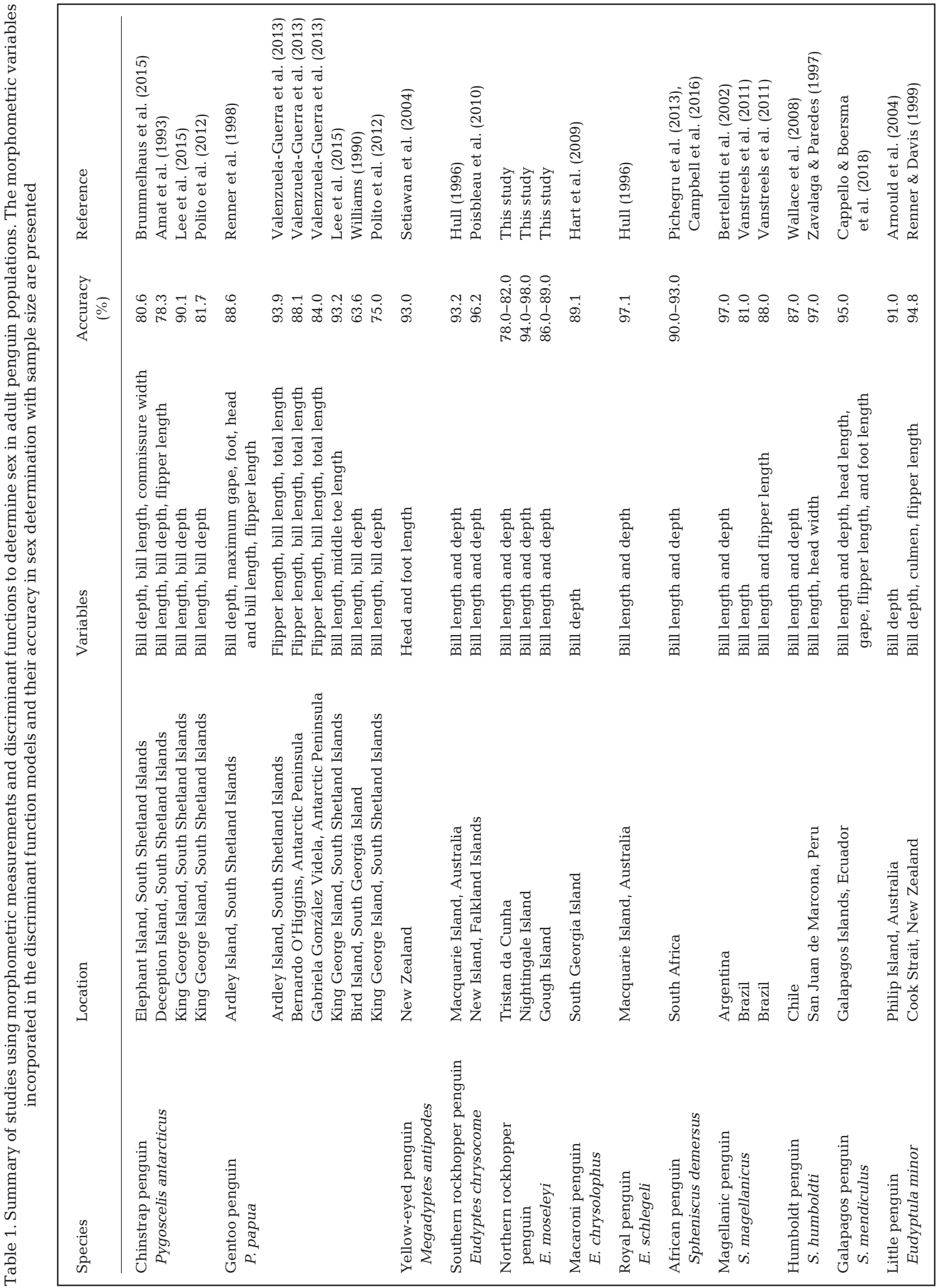




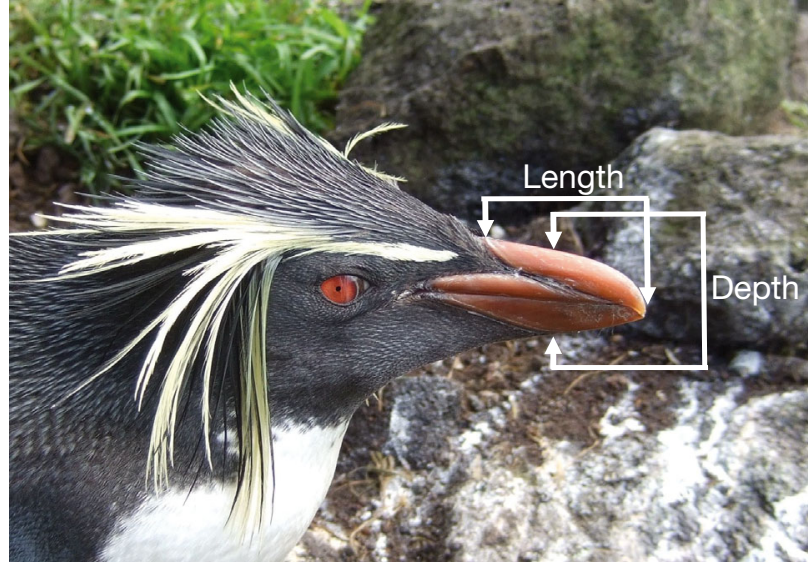

Fig. 1. Morphometric measurements taken on a northern rockhopper penguins showing bill depth and bill length (photo: J.M.B.)

laboratories: Department of Botany, Rhodes University, South Africa and Department of Biology, Marshall University, USA, respectively, using lab-specific methodologies detailed below.

For samples from Tristan da Cunha, total genomic DNA was extracted from a 50-100 $\mu$ l aliquot of blood using a QIAGEN DNeasy ${ }^{\circledR}$ Blood and Tissue Kit, following the manufacturer's instructions, and stored at $-20^{\circ} \mathrm{C}$. A multiplex polymerase chain reaction (PCR) was performed to amplify DNA using the existing primers 2945F (5'-AGA AAA AGA TGG TGT TAG AT-3'), cfR (5'-CAT AAC TCC TTA CCA CAT AT-3') and 3224R (5'-TTG AAC TGT GAA AGC AAC TC-3') (Ellegren 1996). Primer 3224R, when used in conjunction with primer 2945F, generates a $630 \mathrm{bp}$ fragment in both sexes, whilst the combination of primers $\mathrm{cfR}$ and $2945 \mathrm{~F}$ generates a $210 \mathrm{bp}$ fragment in females, allowing the sexes to be easily distinguished by electrophoresis of PCR products. PCR amplification reactions $(0.05 \mu \mathrm{l}$ Bioline BioTaq ${ }^{\mathrm{TM}}$ DNA polymerase, $2 \mu \mathrm{l} 10 \times \mathrm{NH}_{4}$ reaction buffer [Bioline], $0.16 \mathrm{mM}$ of each deoxyribonucleotide triphosphate [dNTP], $4 \mathrm{mM} \mathrm{MgCl}_{2}, 0.4 \mu \mathrm{M}$ each primer and $2 \mu \mathrm{l}$ DNA template) were made up to a total volume of $20 \mu$ l. The PCR thermal profile comprised a single cycle of $94^{\circ} \mathrm{C}$ for $3 \mathrm{~min}$ (denaturation), $55^{\circ} \mathrm{C}$ for $30 \mathrm{~s}$ (annealing) and $72^{\circ} \mathrm{C}$ for $60 \mathrm{~s}$ (extension), followed by 34 cycles of $94^{\circ} \mathrm{C}(30 \mathrm{~s})$, $50^{\circ} \mathrm{C}(30 \mathrm{~s})$, and $72^{\circ} \mathrm{C}(45 \mathrm{~s})$. The program was completed with a final extension step of $72^{\circ} \mathrm{C}$ for $5 \mathrm{~min}$. A total of $5 \mu$ PCR product was bound with $\mathrm{SYBR}^{\circledR}$ Green and analysed by electrophoresis on a $1.5 \%$ agarose gel. Products were examined under UV light for the presence of a single band (male) or double bands (female) (Griffiths et al. 1998).
For samples from Nightingale and Gough islands, total genomic DNA was extracted using standard phenol-chloroform protocols and followed by ethanol washes. PCR was performed using the primers SEX1 (5'-CTC CCA AGG ATG AGA AAC TGT GCA AAA CAG GTA-3') and SEX2 (5'-CCT TCA CTT CCA TTA AAG CTG ATC TGG AAT TTC-3') following Wang \& Zhang (2009). These primers were chosen as they have increased accuracy with lower DNA concentrations (Wang \& Zhang 2008). For each well, $15 \mu \mathrm{l}$ of a $240 \times$ solution of PCR water $(375 \mu \mathrm{l})$, primers $\left(120 \mu \mathrm{l}\right.$ each), BioLabs ${ }^{\circledR}$ Q5 ${ }^{\circledR}$ High-Fidelity $2 \times$ Master Mix (1200 $\mu \mathrm{l})$ was added to $5 \mu \mathrm{l}$ of DNA (25 $\mathrm{ng}$ ). Thermal cycling was set on ST55, which included an initial cycle at $95^{\circ} \mathrm{C}(5 \mathrm{~min}), 30$ cycles of $95^{\circ} \mathrm{C}(1 \mathrm{~min})$, $55^{\circ} \mathrm{C}(1 \mathrm{~min})$, and $72^{\circ} \mathrm{C}(2 \mathrm{~min})$, and a final cycle at $72^{\circ} \mathrm{C}(10 \mathrm{~min})$. Following PCR, $20 \mu \mathrm{l}$ of product and $3 \mu \mathrm{l}$ of BioLabs ${ }^{\circledR}$ Gel Loading Dye (Purple 6X) were pipetted onto a $3 \%$ agarose gel stained with ethidium bromide for electrophoresis. After $200 \mathrm{Vh}$, bands were analysed using a BioRad Molecular Imager ${ }^{\circledR}$. Samples producing a single band were scored as male, and those showing 2 bands as female (Griffiths et al. 1998).

\subsection{Statistical analysis}

A 2-way PERMANOVA was used to test for differences in bill size (BD and BL) among the factors (fixed, orthogonal) 'island' (3 levels: Tristan da Cunha, Nightingale, Gough) and 'sex' (2 levels: male, female). PERMANOVA post-hoc tests (p-pht) were used to explore significant effects. Homogeneity of multivariate dispersion for each factor was tested using the distance-based test PERMDISP prior to PERMANOVA analyses ( $p>0.05$ in both cases). SIMPER analysis was performed for each factor to determine the contribution of $\mathrm{BD}$ and $\mathrm{BL}$ to differences between sexes and among islands. PRIMER v. 6.1, PERMANOVA+ for PRIMER routines (Anderson et al. 2008) was used for all statistical tests. The dimorphism index (DI) was calculated as

$$
\left(\frac{\overline{\boldsymbol{X}}_{\text {male }}}{\overline{\boldsymbol{X}}_{\text {female }}}-1\right)
$$

with the mean size $(\bar{x})$ for BD (BL) of the male divided by the mean size of the female where positive values indicate larger males, negative values that females are larger, and zeros mean the sexes are identical (Fairbairn 2007).

Because there were significant differences in bill measurements among islands, separate discriminant 
functions were developed for each site, as well as one pooling all locations (ultimately, for use with birds of unknown origin; Rollinson et al. 2014). Cross-validation was performed based on 1000 iterations with randomized training and test subsets of data generated in each iteration and built a linear discriminant function using the training data set for predicting birds' sex using the function lda in the package MASS in R 3.3.3 (Ripley et al. 2012, R Core Team 2017) using backward selection, with BL and BD as predictors of sex. The obtained discriminant function was then applied to the test data set to verify the accuracy of the DFA (Hastie et al. 2009). This allowed us to calculate the discriminant score, $D$, for varying probabilities of assignment to either female or male (Table 2). Cohen's $\kappa$ (Cohen 1960) was used to test whether assignment from the discriminant function was better than chance, using an alpha level of 0.05 .

\section{RESULTS}

Blood samples and morphometric measurements of northern rockhopper penguins were taken from 416 birds in total, with 124 from Tristan da Cunha (75 females, 49 males), 149 from Nightingale Island (90 females, 59 males) and 143 from Gough Island (80 females, 63 males). Table 3 presents the bill measurements for examined study birds. All sexes were confirmed by molecular analysis (see the Supplement at www.int-res.com/articles/suppl/n039p293_supp.xlsx for all measurements).

A significant interaction of 'island $\times$ sex' was observed for the 2 measurements, BL and BD (PERMANOVA, $\left.F_{2,407}=3.02, p=0.026\right)$. On each island, males were the larger sex in terms of both BL and BD (p-pht, p < 0.001; Table 3, Figs. 2 \& 3), with the DI ranging from 0.088 to 0.160 depending on the island and parameter (Table 3).

There were also significant differences in bill size among islands, with birds from Gough Island having
Table 3. Bill measurements of female and male northern rockhopper penguins Eudyptes moseleyi from Tristan da Cunha, Nightingale and Gough islands. BD: bill depth; BL: bill length. The positive dimorphism index (DI) indicates that males are the larger sex; for further details see Section 2.3. Values are means with standard deviation (range)

\begin{tabular}{|cccc|}
\hline & Females & Males & DI \\
\hline Tristan & $\mathrm{n}=75$ & $\mathrm{n}=49$ & \\
BL (mm) & $42.3 \pm 2.7$ & $46.7 \pm 2.5$ & 0.104 \\
& $(37.0-48.2)$ & $(40.4-51.0)$ & \\
BD (mm) & $21.7 \pm 1.7$ & $23.6 \pm 2.3$ & 0.088 \\
& $(17.4-25.5)$ & $(18.0-28.0)$ & \\
Nightingale & $\mathrm{n}=90$ & $\mathrm{n}=59$ & \\
BL (mm) & $42.2 \pm 1.6$ & $47.7 \pm 2.1$ & 0.130 \\
& $(39.4-48.3)$ & $(40.6-51.4)$ & \\
BD (mm) & $17.4 \pm 1.2$ & $19.7 \pm 1.3$ & 0.130 \\
& $(14.5-22.3)$ & $(16.7-23.1)$ & \\
Gough & $\mathrm{n}=80$ & $\mathrm{n}=63$ & \\
BL (mm) & $43.9 \pm 2.7$ & $49.4 \pm 1.9$ & 0.125 \\
& $(39.3-51.0)$ & $(44.6-54.5)$ & \\
BD (mm) & $18.8 \pm 1.3$ & $21.8 \pm 1.1$ & 0.160 \\
& $(26.3-23.1)$ & $(19.5-24.1)$ & \\
\hline
\end{tabular}

longer bills and birds from Tristan da Cunha having deeper bills than birds from the other islands (p-pht, $p<0.001$ in all cases; Table 3, Fig. 2). BL contributed most to the dissimilarity between sexes and across all islands (SIMPER, 78\%), with males' bills being significantly larger than those of females at all 3 sites (Table 3, Figs. 2 \& 3). Of the 2 bill measurements, BL contributed $68 \%$ to the dissimilarity between birds from Gough and Nightingale, and $59 \%$ to the dissimilarity between birds from Gough and Tristan da Cunha. Differences in bill size between birds from Nightingale and Tristan da Cunha were more attributed to $\mathrm{BD}$, which contributed $69 \%$ to overall dissimilarity.

Island-specific discriminant functions correctly classified $82-94 \%$ of individuals, and all functions performed significantly better than chance (Cohen's $\kappa=0.63-0.88$, all $p<0.001$; Table 2). Cross-validation

Table 2. Discriminant functions, correct classification rates (percentage of birds correctly classified), cross-validation rates (results from 1000 iterations using newly generated training and test subsets of data) and Cohen's $\kappa$ for functions predicting the sex of northern rockhopper penguins. Individuals with positive discriminant scores $(D>0)$ are classified as males, while those with negative scores $(D<0)$ are classified as females. BD: bill depth; BL: bill length. See Section 2.3 for details

\begin{tabular}{|lcccc|}
\hline Island & Function & $\begin{array}{c}\text { Correct } \\
\text { classification }(\%)\end{array}$ & $\begin{array}{c}\text { Mean cross-validation } \\
(\min .-\max )(\%)\end{array}$ & $\begin{array}{c}\text { Cohen's } \kappa(\mathrm{p}) \\
\text { Tristan da Cunha }\end{array}$ \\
Nightingale & $D=0.39 \times \mathrm{BD}+1.25 \times \mathrm{BL}-43.88$ & 82 & $80(70-89)$ & $0.63(<0.001)$ \\
Gough & $D=0.24 \times \mathrm{BD}+0.99 \times \mathrm{BL}-49.27$ & 94 & $95(92-100)$ & $0.88(<0.001)$ \\
All islands & $D=0.11 \times \mathrm{BD}+0.54 \times \mathrm{BL}-26.86$ & 88 & $90(84-96)$ & $0.77(<0.001)$ \\
& $D=0.26 \times \mathrm{BD}+0.55 \times \mathrm{BL}-30.60$ & 86 & $88(83-92)$ & $0.71(<0.001)$ \\
\hline
\end{tabular}



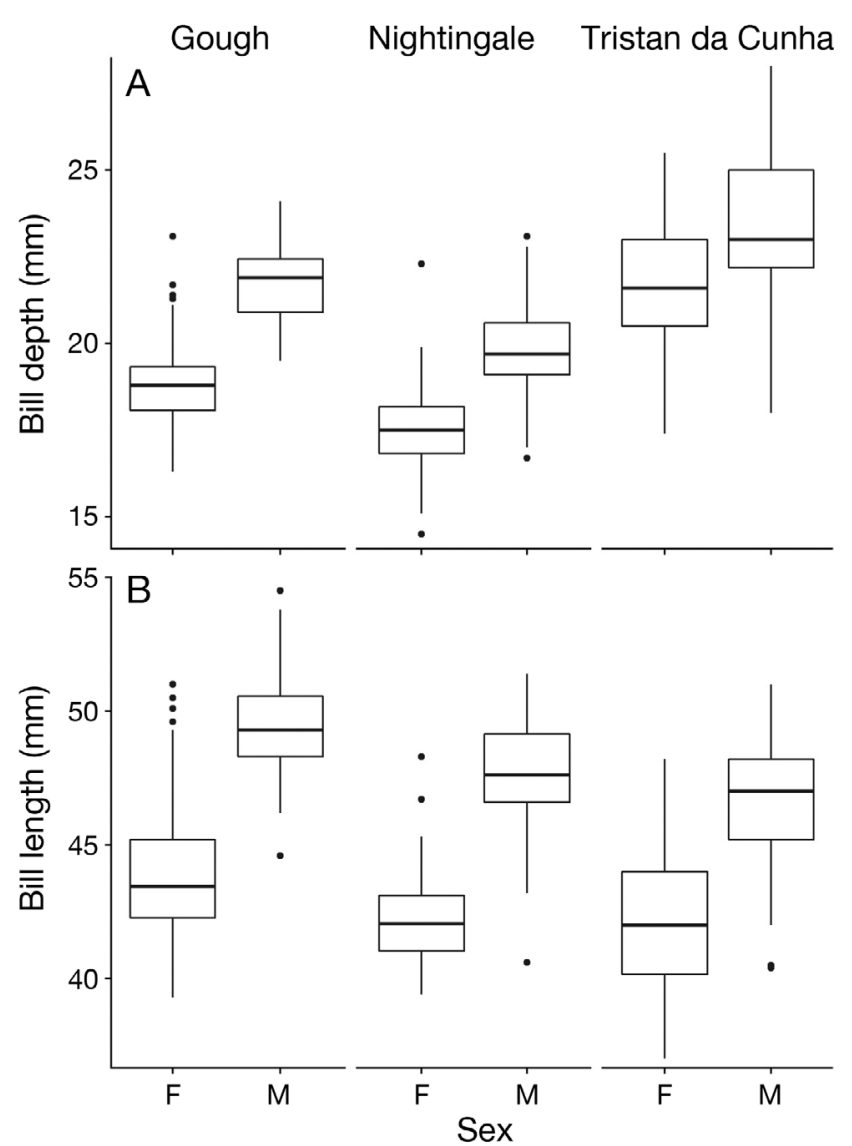

Fig. 2. Comparison of morphometric measurements of $(A)$ bill depth and (B) bill length between sexes (F: female; $M$ : male) and across islands: Gough ( $\mathrm{n}=80$ females, 63 males), Nightingale ( $\mathrm{n}=90$ females, 59 males), Tristan da Cunha ( $\mathrm{n}=75$ females, 49 males). Horizontal line shows the median, with the box representing the lower quartile (25\%) and upper quartile $(75 \%)$, lower whisker $(5 \%)$ and upper whisker $(95 \%)$. Black dots indicate outliers

results from 1000 iterations using newly generated training and test subsets of data also achieved a high rate of correct classification (80-95\%; Table 2). The model for Nightingale Island correctly classified the greatest proportion of individuals (correct classification: $94 \%$, mean cross-validation: 95\%), while that for Tristan da Cunha performed the poorest (correct classification: $82 \%$; mean cross-validation: $80 \%$ ). A discriminant function derived from all sites achieved on average the same accuracy as island-specific functions (correct classification: 86\%, mean crossvalidation: $88 \%$, Cohen's $\kappa=0.71$; Table 2).

\section{DISCUSSION}

We investigated the degree of sexual size dimorphism in adult northern rockhopper penguins across the species' breeding range in the Atlantic Ocean and found site-specific differences in both BL and BD, with males being the larger sex on each island. Penguins, like many sexually monomorphic birds, have been shown to exhibit subtle but distinct morphological differences between the sexes (Agnew \& Kerry 1995, Williams 1995; Table 1). Given the close proximity of northern rockhopper penguins' breeding sites in the South Atlantic Ocean, the geographic variation in sexual size differences we found in penguins breeding in the islands was unexpected. A recent study on African penguins showed no geographic morphological variation across their breeding range (Campbell et al. 2016).

While morphological differentiation may be a consequence of ancestral colonisation and subsequent diversification, environmental factors have also been shown to be important forces driving intercolony variation (Jakubas et al. 2014, Ratcliffe et al. 2014, Yamamoto et al. 2016). Gough Island lies south of the Subtropical Front, whereas Tristan da Cunha, Nightingale, and Inaccessible islands are located to the north (Ryan 2007). This frontal system places the islands in 2 different biogeographical regions, resulting in differences in phenology, foraging areas, and potentially diet (Booth \& McQuaid 2013, Cuthbert 2013, BirdLife International 2018). Discrete foraging behaviours, distributions, and habitat use of the northern rockhopper penguin during both the breeding and non-breeding seasons (BirdLife International 2018) combined with adult breeding philopatry (Cuthbert 2013) and geographic isolation may have led to morphological differentiation with potential functional implication (Booth \& McQuaid 2013, GutiérrezPinto et al. 2014, Jakubas et al. 2014). Different oceanographic conditions and the distance separating Gough Island from the Tristan da Cunha archipelago probably affect prey assemblages and abundance and may have favoured geographic variation in bill size as a result of fitting to local environmental conditions.

Whereas spatial segregation in both foraging areas and breeding sites may explain the difference in morphometric measurements between birds on Gough and the northern islands, intraspecific niche partitioning might be responsible for morphological differentiation between Tristan da Cunha and Nightingale islands (Booth \& McQuaid 2013, Ratcliffe et al. 2014). For example, a recent study showed that despite the short distance of $20 \mathrm{~km}$ separating the neighbouring islands Inaccessible and Nightingale, penguins tracked on either island during the guard phase in 2016 exhibited little spatial overlap (A. Steinfurth et al. unpubl data). Furthermore, based on a stable-iso- 


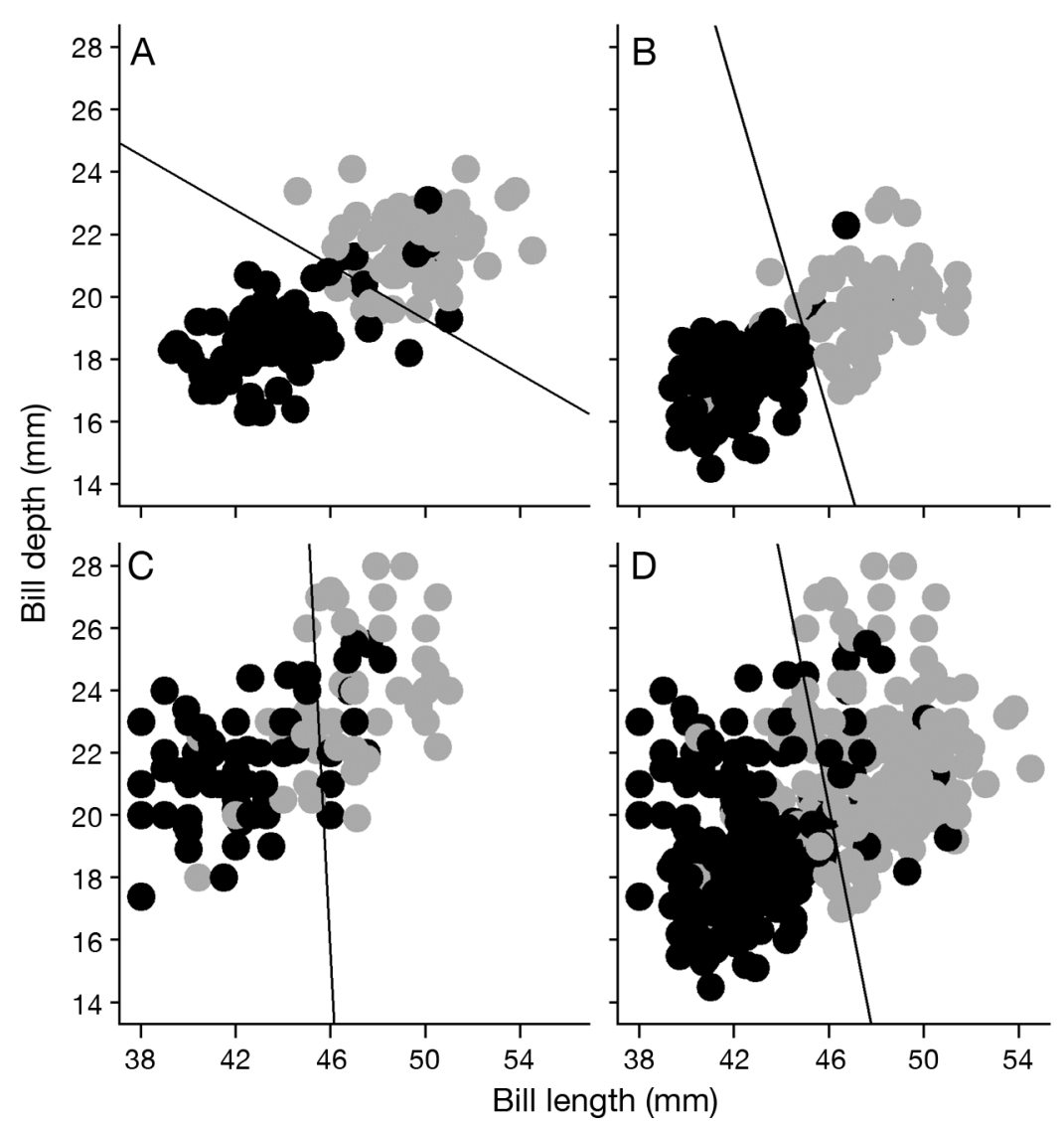

Fig. 3. Bill lengths and depths of northern rockhopper penguins at (A) Gough ( $\mathrm{n}=80$ females, 63 males), (B) Nightingale ( $\mathrm{n}=90$ females, 59 males), (C) Tristan da Cunha ( $\mathrm{n}=75$ females, 49 males), (D) all islands ( $\mathrm{n}=245$ females, 171 males). Solid lines represent the statistical boundary between females (black points) and males (grey points), derived from the discriminant function

tope investigation, birds from Tristan and Nightingale are known to display spatial segregation in their foraging grounds during the pre-moult period, and they also forage on a different trophic level during this time (Booth \& McQuaid 2013). Body size in both sexes may have evolved to adapt to different niches and to exploit a wider range of resources. Similarly, the differences in bill size may have equally evolved as a mechanism to avoid resource competition or enhance feeding efficiency by differential niche-utilisation on an intercolony scale.

The discriminant function for Nightingale Island provided the highest accuracy in determining the sex correctly (94-95\%), which is comparable to results derived by Hull (1996) and Poisbleau et al. (2010) for the southern species (Table 1), while the method performed comparably poorly for the Tristan da Cunha birds (80-82\%; Table 2). The lack of resource competition between sexes, birds being less specialised or birds simply targeting a different diet on Tristan compared to the other islands may have resulted in higher variability in bill sizes of both sexes (Booth \& McQuaid 2013).

Despite the geographic differences, a discriminant function derived from all sites accurately sexed $86-88 \%$ of northern rockhopper penguins and therefore achieved, on average, a similar accuracy as island-specific functions, which can be useful when the colony of origin is unknown, such as in the case of vagrant birds, museum specimens, or individuals outside the breeding season (De Dinechin et al. 2007, Rollinson et al. 2014).

The use of a DFA approach, however, must come with caveats, and the possibility of observer bias or error in measurements cannot be disregarded (Hull 1996). Measurement variability due to human error is often partly due to methodological and instrumental error. For example, a major source of methodological error is based on slight variations in the exact positioning of the calliper. In our study, a standardised method was applied by highly experienced field teams on each island using repeat measurements of clearly defined morphometric features, BL and BD, that are large relative to the precision of the measurement, with lower measurement error rates than other features (Arnqvist \& Mårtensson 1998). Hard body parts, such as the bill, tarsus and culmen, are therefore preferable for measurements over soft parts, e.g. the tail length, or parameters that might fluctuate seasonally such as body mass (e.g. Poisbleau et al. 2010, Pichegru et al. 2013, Campbell et al. 2016). BL was the parameter that contributed most to the dissimilarity between the sexes and has more confined landmark locations than $\mathrm{BD}$; hence, measurements of this parameter would be expected to vary less between observers (Arnqvist \& Mårtensson 1998). Repeat measurements, as we performed in our study, can further help to ensure accurate results and repeatability. Certain instruments are also more prone to error than others, and we minimised this error by using the same brand and style of callipers throughout the data collection as well as across sampling sites. In addition, age and overall size have potentially confounding effects, because males must grow through the female range of sizes before reaching the male 
threshold (Bertellotti et al. 2002), and vice versa, large females may be incorrectly identified as males. Consequently, a sampling bias towards younger or older individuals could be problematic (e.g. Hart et al. 2009, Poisbleau et al. 2010). Whilst the overall DF developed here accurately predicted the sex of $86-89 \%$ of northern rockhopper penguins, some birds would have been classified incorrectly without molecular analysis.

Despite these potential problems, the use of DFA to determine sex has generally been successful, and the overall accuracy obtained in this study was similar to that reported for many other penguin species and better than many functions for Eudyptes spp. penguins (Table 1). In addition, morphometric data can be supplemented with behavioural observation, providing the behaviours observed can be reliably assigned to a specific sex (e.g. incubation shift patterns, courtship displays; Wagner 1999). Northern rockhopper penguins, like all crested penguins, have a synchronised breeding cycle with highly defined parental shifts in nest attendance (Cuthbert 2013), which when combined with morphometrics allows for even greater certainty of individuals' sex and explains why none of the birds captured during the guard stage were sexed incorrectly in the field. Comparing birds within pairs could further improve accuracy for predicting the individual's sex (Fletcher \& Hamer 2003) when, as in our study, the larger bird within a breeding pair could be assumed to be the male (Warham 1975).

In summary, whereas molecular analysis conclusively determines an individual's sex, in northern rockhopper penguins morphometric measurements can provide a reasonably reliable, simple and rapid alternative using a less invasive technique compared to other methods. This might be particularly important when working with this and other threatened species. Owing to historic and ongoing population declines, combined with the northern rockhopper penguin's small breeding range and vulnerability to land- and sea-based threats (Trathan et al. 2015, BirdLife International 2018), the species was classified as Endangered by BirdLife International in 2008 and included in the IUCN Red List of Threatened Species. Declines in many species of penguins mean that population surveys, while providing a valuable tool to estimate annual population sizes, are of little help in identifying and understanding factors that are driving population trends and dynamics. Consideration of sex-specific differences in future ecological studies will aid investigation of a potential sexdependent vulnerability in this Endangered species.
Acknowledgements. This study was funded by the Department of Environment, Food and Rural Affairs, Fauna and Flora International, the South African Research Chairs Initiative of the Department of Science and Technology, the South African National Research Foundation, BirdLife International, BirdLife South Africa, the South African Department of Environmental Affairs, and the Royal Society for the Protection of Birds. Animal ethics approval was given by the Ethics Committees of Rhodes University and the University of Cape Town, South Africa. Marco Fusi provided statistical advice. We are grateful to the Administrator and Island Council of Tristan for permission to visit and carry out fieldwork, and the Tristan da Cunha Conservation Department for logistical support and assistance in the field. We thank the overwintering teams for their invaluable help collecting the samples on Gough Island.

\section{LITERATURE CITED}

Agnew DJ, Kerry R (1995) Sexual dimorphism in penguins. In: Dann P, Norman I, Reilly P (eds) The penguins. Beatty and Sons, Sydney, p 299-271

Amat JA, Vinuela J, Ferrer M (1993) Sexing chinstrap penguins (Pygoscelis antarctica) by morphological measurements. Waterbirds 16:213-215

Anderson M, Gorley RN, Clarke RK (2008) Permanova+ for Primer: guide to software and statistical methods. Plymouth Marine Laboratory, Plymouth

Arnould JPY, Dann P, Cullen JM (2004) Determining the sex of little penguins (Eudyptula minor) in northern Bass Strait using morphometric measurements. Emu 104:261-265

Arnqvist G, Mårtensson T (1998) Measurement error in geometric morphometrics: empirical strategies to assess and reduce its impact on measures of shape. Acta Zool Acad Sci Hung 44:73-96

* Banks J, Van Buren A, Cherel Y, Whitfield JB (2006) Genetic evidence for three species of rockhopper penguins, Eudyptes chrysocome. Polar Biol 30:61-67

Bertellotti M, Tella JL, Godoy JA, Blanco G, Forero MG, Donázer JA, Ceballos O (2002) Determining the sex of Magellanic penguins using molecular procedures and discriminant functions. Waterbirds 25:479-484

BirdLife International (2018) Eudyptes moseleyi. The IUCN Red List of Threatened Species 2018: e.T22734408A 132664126. http://dx.doi.org/10.2305/IUCN.UK.2018-2. RLTS. T22734408A132664126.en (accessed 11 August 2019)

Boersma PD, Davies EM (1987) Sexing monomorphic birds by vent measurements. Auk 104: 779-783

Booth JM, McQuaid CD (2013) Northern rockhopper penguins prioritise future reproduction over chick provisioning. Mar Ecol Prog Ser 486:289-304

Brummelhaus J, Valiati VH, Petry MV (2015) Morphometric variation in chinstrap penguins: molecular sexing and discriminant functions in the South Shetland Islands, Antarctica. Antarct Sci 27:327-332

Campbell KJ, Farah D, Collins S, Parsons NJ (2016) Sex determination of African penguins Spheniscus demersus using bill measurements: method comparisons and implications for use. Ostrich 87:47-55

Cappello CD, Boersma PD (2018) Sexing Galapagos penguins Spheniscus mendiculus by morphological measurements. Endang Species Res 35:169-173

Cohen J (1960) A coefficient of agreement for nominal 
states. Educ Psychol Meas 20:37-46

Cortés V, García-Barcelona S, González-Solís J (2018) Sexand age-biased mortality of three shearwater species in longline fisheries of the Mediterranean. Mar Ecol Prog Ser 588:229-241

Croxall JP (1995) Sexual size dimorphism in seabirds. Oikos 73:399-403

Cuthbert RJ (2013) Northern rockhopper penguin (Eudyptes moseleyi). In: Borboroglu P, Boersma PD (eds) Penguins. Natural history and conservation. University of Washington Press, Seattle, WA, p 131-143

Cuthbert R, Cooper J, Burle MH, Glass CJ and others (2009) Population trends and conservation status of the northern rockhopper penguin Eudyptes moseleyi at Tristan da Cunha and Gough Island. Bird Conserv Int 19:109-120

De Dinechin M, Pincemy G, Jouventin P (2007) A northern rockhopper penguin unveils dispersion pathways in the Southern Oceans. Polar Biol 31:113-115

Ellegren H (1996) First gene on the avian W chromosome (CHD) provides a tag for universal sexing of non-ratite birds. Proc Biol Sci 263:1635-1641

Fairbairn DJ (2007) Introduction: the enigma of sexual size dimorphism. In: Fairbairn DJ, Blanckenhorn WU, Székely T (eds) Sex, size and gender roles: evolutionary studies of sexual dimorphism. Oxford University Press, Oxford, p 1-10

* Fletcher KL, Hamer KC (2003) Sexing terns using biometrics: the advantage of within-pair comparisons. Bird Study 50: 78-83

Gaston AJ (2004) Seabirds: a natural history. Yale University Press, New Haven, CT

*Griffiths R, Double MC, Orr K, Dawson RJ (1998) A DNA test to sex most birds. Mol Ecol 7:1071-1076

*Gutiérrez-Pinto N, McCracken KG, Alza L, Tubaro P, Kopuchian C, Astie A, Cadena CD (2014) The validity of ecogeographical rules is context-dependent: testing for Bergmann's and Allen's rules by latitude and elevation in a widespread Andean duck. Biol J Linn Soc 111:850-862

Hart T, Fitzcharles E, Trathan PN, Coulson T, Rogers AD (2009) Testing and improving the accuracy of discriminant function tests: a comparison between morphometric and molecular sexing in macaroni penguins. Waterbirds 32:437-443

Hastie T, Tibshirani R, Friedman J (2009) The elements of statistical learning: data mining, inference, and prediction, $2^{\text {nd }}$ edn. Springer, New York, NY

Hildebrandt TB, Goritz F, Bosch H, Seidel B, Pitra C (1996) Ultrasonographic sexing and reproductive assessment of penguins. Penguin Conserv 9:6-12

Hull CL (1996) Morphometric indices for sexing adult royal Eudyptes schlegeli and rockhopper E. chrysocome penguins at Macquarie Island. Mar Ornithol 24:23-27

Jakubas D, Wojczulanis-Jakubas K, Jensen JK (2014) Body size variation of European storm petrels Hydrobates pelagicus in relation to environmental variables. Acta Ornithol 49:71-82

Jouventin P, Cuthbert RJ, Ottval R (2006) Genetic isolation and divergence in sexual traits: evidence for the northern rockhopper penguin Eudyptes moseleyi being a sibling species. Mol Ecol 15:3413-3423

Kerry KR, Agnew DJ, Clarke JR, Else GD (1992) The use of morphometric parameters for the determination of sex of Adélie penguins. Wildl Res 19:657-666

Le Bohec C, Durant JM, Gauthier-Clerc M, Stenseth NC and others (2008) King penguin population threatened by
Southern Ocean warming. Proc Natl Acad Sci USA 105: 2493-2497

Kee WY, Jung JW, Han YD, Chung H, Kim JH (2015) A new sex determination method using morphological traits in adult chinstrap and gentoo penguins on King George Island, Antarctica. Anim Cells Syst 19:156-159

*Pichegru L, Cook T, Handley J, Voogt N, Watermeyer J, Nupen L, McQuaid CD (2013) Sex-specific foraging behaviour and a field sexing technique for Endangered African penguins. Endang Species Res 19:255-264

Poisbleau M, Demongin L, Van Noordwijk HJ, Strange IJ, Quillfeldt P (2010) Sexual dimorphism and use of morphological measurements to sex adults, immatures and chicks of rockhopper penguins. Ardea 98:217-224

Polito MJ, Clucas GV, Hart T, Trivelpiece WZ (2012) A simplified method of determining the sex of Pygoscelis penguins using bill measurements. Mar Ornithol 40:89-94

R Core Team (2017) R: a language and environment for statistical computing. Version 3.3.3. R Foundation for Statistical Computing, Vienna

Ratcliffe N, Crofts S, Brown R, Baylis AMM and others (2014) Love thy neighbour or opposites attract? Patterns of spatial segregation and association among crested penguin populations during winter. J Biogeogr 41: 1183-1192

Renner M, Davis LS (1999) Sexing little penguins Eudyptes minor from Cook Strait, New Zealand using discriminant function analysis. Emu 99:74-79

Renner M, Valencia J, Davis LS, Saez D, Cifuentes O (1998) Sexing of adult gentoo penguins in Antarctica using morphometrics. Waterbirds 21:444-449

* Ripley B, Venables B, Hornik K, Gebhardt A, Firth D (2012) MASS: functions and datasets to support Venables and Ripley, 'Modern Applied Statistics with S' (4th edition, 2002). R package version 7.3-23. http://CRAN.R-project.org/package $=$ MASS

Robson B, Glass T, Glass N, Glass J and others (2011) Revised population estimate and trends for the Endangered northern rockhopper penguin Eudyptes moseleyi at Tristan da Cunha. Bird Conserv Int 21:454-459

Rollinson DP, Reynolds C, Paijmans DM (2013) Vagrant northern rockhopper penguin at Soetwater Beach. Ornithol Obs 4:36-38

Ryan P (2007) Field guide to the animals and plants of Tristan da Cunha and Gough Island. Pisces Publications, Newbury

Samour HJ, Stevenson M, Knight JA, Lawrie AJ (1983) Sexing penguins by cloacal examination. Vet Rec 113: 84-85

Setiawan AN, Darby JT, Lambert DM (2004) The use of morphometric measurements to sex yellow-eyed penguins. Waterbirds 27:96-101

* Trathan PN, García-Borboroglu P, Boersma D, Bost CA and others (2015) Pollution, habitat loss, fishing, and climate change as critical threats to penguins. Conserv Biol 29: 31-41

Valenzuela-Guerra P, Morales-Moraga D, González-Acuña D, Vianna JA (2013) Geographic morphological variation of gentoo penguin (Pygoscelis papua) and sex identification: using morphometric characters and molecular markers. Polar Biol 36:1723-1734

Vanstreels RET, Corrado Adornes A, Puoppolo V, Lima Canabarro P, Pinho Silva-Filho R, Catao-Doas JL (2011) Gender determination from morphometrics in migrating Magellanic penguins Spheniscus magellanicus. Mar 
Ornithol 39:215-220

Wagner RH (1999) Sexual size dimorphism and assortative mating in razorbills (Alca torda). Auk 116:542-544

Wallace RS, Dubach J, Michaels MG, Keuler NS and others (2008) Morphometric determination of gender in adult Humboldt penguins (Spheniscus humboldti). Waterbirds 31:448-453

Wang N, Zhang ZW (2009) The novel primers for sex identification in the brown eared-pheasant and their application to other species. Mol Ecol Res 9:186-188

Warham J (1972) Breeding seasons and sexual dimorphism in rockhopper penguins. Auk 89:86-105

Warham J (1975) The crested penguins. In: Stonehouse B (ed)

Editorial responsibility: Sandra Hochscheid, Naples, Italy
The biology of penguins. Macmillan, London, p 189-269

Williams TD (1990) Annual variation in breeding biology of gentoo penguins, Pygoscelis papua, at Bird Island, South Georgia. J Zool (Lond) 222:247-258

Williams TD (1995) The penguins. Oxford University Press, Oxford

* Yamamoto T, Kohno H, Mizutani A, Yoda K and others (2016) Geographical variation in body size of a pelagic seabird, the streaked shearwater Calonectri leucomelas. J Biogeogr 43:801-808

Zavalaga CB, Paredes R (1997) Sex determination of adult Humboldt penguins using morphometric characters. J Field Ornithol 68:102-112

Submitted: December 17, 2018; Accepted: June 13, 2019

Proofs received from author(s): August 11, 2019 